\title{
Correction to: Biological control of Phytophthora blight by Pseudomonas protegens strain 14D5
}

\section{Xiao Yang • Chuanxue Hong}

Published online: 13 January 2020

(C) Koninklijke Nederlandse Planteziektenkundige Vereniging 2020

\section{Correction to: Eur J Plant Pathol https://doi.org/10.1007/s10658-019-01909-6}

This erratum is published as vendor overlooked several author corrections related with Table $1 \& 2$ during proofing. 